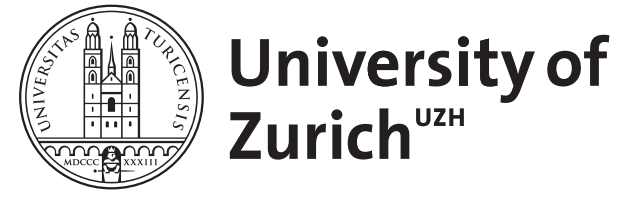

\title{
Negative Appraisals
}

Freydefont, Laure

DOI: https://doi.org/10.1007/978-3-319-28099-8_826-1

Posted at the Zurich Open Repository and Archive, University of Zurich

ZORA URL: https://doi.org/10.5167/uzh-157371

Book Section

Accepted Version

Originally published at:

Freydefont, Laure (2018). Negative Appraisals. In: Zeigler-Hill, Virgil; Shackelford, Todd K. Encyclopedia of Personality and Individual Differences. Cham: Springer, Epub ahead of print.

DOI: https://doi.org/10.1007/978-3-319-28099-8_826-1 


\title{
Encyclopedia of Personality and Individual Differences
}

\section{Negative appraisals}

\author{
Laure Freydefont
}

\section{Appraisal theories and the origin of negative appraisals}

Although the term of appraisal has been commonly used in the literature since several decades (Arnold, 1960), the controversy regarding the structure and the function of appraisal remains a current concern. The present article will first describe the emergence of the term "negative appraisals" in the literature and thus will propose one clear definition of "negative appraisals".

Lazarus and Folkman (1984) defined the concept of appraisal as "a process through which the person evaluates whether a particular encounter with the environment is relevant to his or her well-being". They distinguished two types of appraisal: a primary appraisal and a secondary appraisal. In primary appraisal, people evaluate whether they have anything at stake in the encounter as well as the potential benefits for well-being according to their own personality, values, commitment, etc. In secondary appraisal, people evaluate the opportunities to prevent harm or to improve the prospects for benefit. Thus, various coping strategies (changing the situation, accepting it, seeking more information, or holding back from acting impulsively) can be used. After the individual finishes appraising the valence of the event, the second phase begins which consists of appraising their ability to cope with the event. In this general sense, appraisal can be considered as a cognitive evaluation of different variables or events composing a situation.

Among the numerous theories on appraisal, most of them assume that emotions come from evaluations of events (Lazarus, 1991; Scherer, 2001; Smith \& Ellsworth, 1985) 
rather than the other way around (see Clore \& Ortony, 2001). As people are continually evaluating events from the environment, emotions should result from patterns of evaluation known as appraisal structures (Silvia, 2005). According to numerous authors, cognitive appraisal does not require consciousness and control (Roseman \& Smith, 2001). These appraisal theories define appraisal as the process of detecting and assessing the significance of the environment in order to improve well-being (Moors, Ellsworth, Scherer, \& Frijda, 2013) and do not make distinction between negative nor positive appraisal. However, based on Lazarus' stress model, Lawton, Kleban, Moss, Rovine, \& Glicksman (1989) defined the term "caregiving appraisal" as a large category including cognitive appraisal, affective appraisal and reappraisal of a potential stressor encountered in the environment and the efficacy of one's coping efforts. In this context, caring was defined as "the affective component of one's commitment to the welfare of another", and caregiving being defined as "the behavioural expression of this commitment" (Pearlin, Mullan, Semple, \& Skaff, 1990). Therefore, Lawton and collaborators (1989) conceptualized caregiving satisfaction as representing the constructs of positive and negative appraisal.

\section{Negative appraisals}

"Negative appraisals" is a term less commonly met in the literature. Based on Lawton and colleagues' research, Pruchno, Peters, \& Burant (1995) presented a theoretical model for the understanding of family members' well-being living in multigenerational households. This model includes "negative appraisals" as a variable influencing well-being of caregivers and care-receivers among their own family. Harwood and colleagues (2000) reported a study investigating the influence of the predictors of satisfaction and burden, conceptualized as positive and negative caregiving appraisals among caregivers (according to Lawton et al., 1989). The authors considered negative appraisals as the evaluation of the 
negative influence of caregivers on patient's health. In the same line of research, Toohey and colleagues (2016) use the term negative appraisals as the perceptions of stigma, of losses connected to caregiving.

Moreover, another study by Brown and Jones (2010) used the term negative appraisal in the context of evaluation of the level of pain. In their study, the authors referred to negative appraisal as the negative evaluation of the unpleasantness of the painful stimuli. According to this recent research "negative appraisal" seems to be characterized as an evaluation or estimation of negative event or stimulation. Finally, the term "negative appraisals" is also found in research on Posttraumatic Stress Disorder (PTSD) (Ehlers \& Clark, 2000; Zuj et al., 2017). In this context, the authors refer to "negative appraisals" as the negative evaluation relating to the trauma and its sequelae. Here also, the use of "negative appraisals" is based on the idea that individuals negatively appreciate an event or a situation.

To conclude, negative appraisals is a recent term which appeared in the psychological literature few decades ago (Lawton et al., 1989). According to the past research and the different use of the term appraisal in the scientific literature, the term "negative appraisals" could be defined as the process through people evaluate or appreciate a particular negative encounter in the environment, which is relevant to his or her wellbeing.

\section{References}

Arnold, M. B. (1960). Emotion and personality (2 vols). New York: Columbia University Press 
Brown, C. A., \& Jones, A. K. P. (2010). Meditation experience predicts less negative appraisal of pain: Electrophysiological evidence for the involvement of anticipatory neural responses. Pain, 150, 428-438. doi: 10.1016/j.pain.2010.04.017

Clore, G. L, \& Ortony, A. (2001). Appraisal Theories How cognition shapes affect into emotion, in M. Lewis, J. A. Haviland-Jones, \& L. Feldman Barret (Eds.), Handbook of emotions, Third edition (pp. 628-642). New York, the Guilford Press.

Ehlers, A., Clark, D.M., 2000. A cognitive model of posttraumatic stress disorder. Behavior Research and Therapy, 38, 319-345. doi: https://doi.org/10.1016/j.jad.2017.04.016

Harwood, D. G., Barker, W. W., Owny, R. L., Bravo, M., Aguero, H., Duara, R. (2000).

Predictors of positive and negative appraisal among Cuban American caregivers of Alzheimer's disease patients. International Journal of Geriatric Psychiatry, 15, 481487. doi: 10.1002/1099-1166(200006)15:6<481::AID-GPS984>3.0.CO;2-J

Lawton, M. P., Kleban, M. H., \& Moss, M. (1989). Measuring caregiving appraisal. Journal of Gerontology: Psychological Sciences, 44, 61-71.

https://academic.oup.com/geronj/article-abstract/44/3/P61/595300/MeasuringCaregiving-Appraisal

Lazarus, R.S. (1991). Emotion and adaptation. New York: Oxford University Press.

Lazarus, R.S., \& Folkman, S. (1984). Stress, appraisal and coping. New York: Springer.

Moors, A., Ellsworth, P. C., Scherer, K. R., \& Frijda, N. H. (2013). Appraisal theories of emotion: State of the art and future development. Emotion Review, 5, 119-124. doi: $10.1177 / 1754073912468165$ 
Pearlin, L. I., Mullan, J. T., Semple, S. J. and Ska., M. M. (1990) Caregiving and the stress process: an overview of concepts and their measures. Gerontologist 30, 583-594, https://academic.oup.com/gerontologist/articleabstract/30/5/583/564941/Caregiving-and-the-Stress-Process-An-Overview

Pruchno, P. A., Peters, N. D. and Burant, C. J. (1995) Mental health of co-resident family caregivers: examination of a two-factor model. Journal of Gerontology: Psychological Sciences, 50B, 247-256. doi: https://doi.org/10.1093/geronb/50B.5.P247

Roseman, I. J., \& Smith, C. A. (2001). Appraisal theory: Overview, assumptions, varieties, controversies. In K. R. Scherer, A. Schorr, \& T. Johnstone (Eds.), Appraisal processes in emotion: Theory, methods, research (pp. 3-19). New York: Oxford University Press. Scherer, K.R. (2001). Appraisal considered as a process of multi-level sequential checking. In K.R. Scherer, A. Schorr, \& T. Johnstone (Eds.). Appraisal processes in emotion: Theory, Methods, Research (pp. 92-120). New York and Oxford: Oxford University Press.

Silvia, P. J. (2005). What is interesting? Exploring the appraisal structure of interest. Emotion, 5, 89-102. doi: 10.1037/1528-3542.5.1.89

Smith, C.A., \& Ellsworth, P.C. (1985). Patterns of cognitive appraisal in emotion. Journal of Personality and Social Psychology, 43, 813-838. doi: http://dx.doi.org/10.1037/00223514.48.4.813

Toohey, M. J., Muralidharan, A., Medoff, D., Lucksted, A., \& Dixon, L. (2016). Caregiver positive and negative appraisals. Effects of the national alliance on mental illness family-to-family intervention. The Journal of Nervous and Mental Disease, 204, 156159. doi: 10.1097/NMD.0000000000000447 
Zuj, D. V., Palmer, M. A., Gray, K. E., Hsu, C. M. K., Nicholson, E. L., Mahli, G. S., Bryant, R. A., \& Felmingham, K. L. (2017). Negative appraisals and fear extinction are independently related to PTSD symptoms. Journal of affective disorders, 217, 246251. doi: https://doi.org/10.1016/j.jad.2017.04.016 